\title{
Agnieszka Płusajska-Otto, Podręcznik pracy głosem. Ćwiczenia i wskazówki dla osób występujących publicznie, Wydawnictwo Uniwersytetu Łódzkiego, Łódź 2017, ss. 245
}

Recenzowana książka, jak sugeruje tytul, jest skierowana do osób występujących publicznie przed większymi i mniejszymi gremiami, czyli tych wszystkich, którzy pracują głosem. Wśród jej odbiorców powinni znaleźć się zatem nauczyciele różnych poziomów kształcenia (od edukacji przedszkolnej po nauczycieli akademickich), prawnicy, dziennikarze, prezenterzy telewizyjni i radiowi, duchowni, a także studenci logopedii, pedagogiki czy aktorstwa. Autorka, będąca logopedą i trenerem emisji głosu, ale także wykładowcą w Szkole Filmowej w Łodzi, dzieli się z czytelnikami swoimi doświadczeniami w pracy nad prawidłową emisją głosu, prezentując konkretne ćwiczenia, a także wytyczne, które pozwolą zachować głos w dobrej kondycji przez długie lata. Książka składa się ze wstępu, dziesięciu rozdziałów, zakończenia, bibliografii oraz aneksu.

Kolejne rozdziały poświęcone są poszczególnym fazom pracy nad prawidłowym wydobywaniem i brzmieniem głosu. Autorka hołduje holistycznemu podejściu do człowieka, który jest jednością psychofizyczną, w związku z czym „psyche” $i$ „soma” wzajemnie na siebie wpływają, co znajduje odbicie w schemacie postępowania: „myśl $\rightarrow$ ciało $\rightarrow$ oddech $\rightarrow$ głos” (s. 16). Zgodnie z regułami metodyki pracy logopedycznej zwraca uwagę na pierwszoplanową rolę oddechu, umiejętność relaksacji oraz prawidłowej postawy ciała dla emisji głosu.

* Zakład Dialektologii Polskiej i Logopedii, Instytut Filologii Polskiej i Logopedii, Wydział Filologiczny Uniwersytetu Łódzkiego, ul. Pomorska 171/173, 90-236 Łódź, e-mail: ewa.gacka@uni.lodz.pl. 
W rozdziale pierwszym Autorka podkreśla znaczenie swobodnej, rozluźnionej postawy ciała dla właściwego funkcjonowania całego organizmu, a więc także aparatu oddechowego, fonacyjnego i artykulacyjnego, mających kluczowe znaczenie dla tworzenia głosu, mówienia. Jak zaznacza: „[p]raca nad postawą to praca nad sobą, to umiejętność obserwowania siebie w sytuacjach dnia codziennego i korygowania błędnych nawyków" (s. 16). Pomocne w realizacji tych celów są precyzyjnie opisane ćwiczenia, przeznaczone do wykonywania w pozycji siedzącej bądź stojącej, które pozwalają zidentyfikować występujące w ciele ewentualne napięcia czy niewłaściwe przyzwyczajenia po to, by je wyeliminować.

Rozdział drugi poświęcony jest relaksacji, która pomaga w kształtowaniu umiejętności odprężenia, pozbycia się napięć, wyciszenia. Autorka daje konkretne wskazówki, jak osiągnąć ten stan, wspomina także o znanych metodach relaksacji według Jacobsona, Schulza czy o przeznaczonej dla dzieci metodzie Wintreberta.

W rozdziale trzecim Dobry oddech dla mowy zaprezentowano liczne ćwiczenia pomagające w opanowaniu prawidłowego typu oddychania - głębokiego, spokojnego, swobodnego, wykonywanego przy udziale przepony, oraz ćwiczenia wydłużania, a także różnicowania siły wydechowej. Czytelnik znajdzie tutaj bogaty wybór tekstów, z których może skorzystać podczas pracy nad wydłużaniem wydechu oraz kształtowaniem umiejętności ekonomicznego gospodarowania powietrzem podczas mówienia. Szkoda tylko (przyjmując, że podręcznik można wykorzystać jako przewodnik w pracy samokształceniowej), że Autorka nie zaznacza jednoznacznie, iż przesadne wydłużanie fazy wydechowej jest niekorzystne. Długa faza wydechu jest sprawą treningu i trzeba postępować rozważnie przy usprawnianiu tego aspektu funkcji oddechowej.

Rozdział czwarty poświęcony jest masażowi, który stanowi istotny element w procesie rozluźnienia ciała. Autorka precyzyjnie definiuje najważniejsze elementy poprawnie wykonanego masażu, obrazowo prezentuje sposób i pozycje, w jakich można go wykonać, a co równie ważne - przybliża ćwiczenia z wykorzystaniem masażu realizowanego w parach oraz automasażu.

O tym, jak ważna jest ogólna kondycja fizyczna człowieka dla emisji głosu, przekonuje rozdział piąty, noszący sugestywny tytuł Rozgrzewka ciała-instrumentu. Nawiązując do zaproponowanego porównania, można podsumować, że tylko odpowiednio nastrojony instrument pozwala na wydobycie pięknie brzmiącego dźwięku. Aktywność fizyczna poprawia nastrój, dodaje energii, ale także - jak zaznacza Agnieszka Płusajska-Otto - pogłębia oddech, poprawia ukrwienie, pobudza myślenie, a to przekłada się na wzrost pewności siebie i poprawę możliwości głosowych (s. 68). Osoby pracujące nad emisją głosu znajdą tu liczne propozycje ćwiczeń ogólnorozwojowych do wykonania w pozycji leżącej, stojącej i na czworakach.

W rozdziale szóstym Sprawny aparat artykulacyjny Autorka wymienia i dokładnie opisuje ćwiczenia usprawniające pracę języka, warg, podniebienia miękkiego, żuchwy oraz pierścienia zwierającego gardła. 
Istotnym elementem w pracy nad prawidłową emisją głosu jest uaktywnienie rezonatorów. Te kwestie zostały omówione w rozdziale siódmym, w którym zaprezentowano ćwiczenia pobudzające pracę rezonatorów: nasady i piersiowego. Także w tym przypadku opis poszczególnych ćwiczeń jest precyzyjny i czytelny.

Zasadzie prawidłowej i wyrazistej wymowy samogłosek i spółgłosek poświęcone są, odpowiednio, rozdziały ósmy i dziewiąty. W rozdziale dotyczącym samogłosek Autorka podaje ich klasyfikacje, dokonuje charakterystyki, a opis wzbogaca schematami poszczególnych głosek, palatogramami oraz labiogramami. Na szczególne podkreślenie zasługuje bardzo bogaty zestaw ćwiczeń pozwalających na wypracowanie wyrazistej artykulacji samogłosek, co, jak wiadomo, jest koniecznym warunkiem prawidłowej dykcji. Analogicznie w rozdziale poświęconym spółgłoskom znalazły się podziały spółgłosek ze względu na różne kryteria: miejsce artykulacji, stopień zbliżenia narządów mowy, udział podniebienia miękkiego, udział więzadeł głosowych, jak również charakterystyka prawidłowego sposobu ich wymawiania. Opis wzbogacono rycinami prezentującymi schematy spółgłosek i ich palatogramami. Rozdział ten zawiera również odpowiednio dobrane zestawy sylab i logatomy pozwalające na ćwiczenie poprawnej wymowy poszczególnych spółgłosek.

W rozdziale dziesiątym Autorka zebrała tak zwane wprawki dykcyjne, czyli specjalnie dobrane teksty o dużym stopniu trudności wymawianiowej, które pozwalają na utrwalanie wyrazistej artykulacji wszystkich głosek w różnych pozycjach wokalicznych. Zaprezentowane „łamańce językowe” stanowią ostatni etap pracy nad głosem.

Układ treści w książce jest czytelny, przejrzysty, a język zrozumiały także dla niespecjalisty, który może skorzystać z niej w pracy samokształceniowej nad doskonaleniem jakości głosu. Poza dokładnym opisem konkretnych ćwiczeń w publikacji znalazły się ilustrujące je fotografie. Część z prezentowanych ćwiczeń znana jest z innych opracowań, pozostałe stanowią autorskie propozycje Agnieszki Płusajskiej-Otto. Zebrane w jedną całość dają możliwość wyboru różnych propozycji spośród podanych. W aneksie zaprezentowano wykorzystywany podczas poszczególnych etapów pracy materiał fonetyczny, zestawy głosek, sylab, wyliczanki, teksty służące doskonaleniu prawidłowej wymowy. Publikacja powstała w oparciu o bogatą literaturę przedmiotu. Autorka korzystała z opracowań nie tylko logopedów, ale też śpiewaków, aktorów, specjalistów od wizerunku, językoznawców, psychologów. Starannie sporządzony spis literatury daje czytelnikom możliwość poszerzenia wiedzy na temat pracy nad emisją głosu z punktu widzenia różnych dziedzin nauki.

Podręcznik pracy głosem. Ćwiczenia i wskazówki dla osób występujących publicznie to książka godna polecenia, zasługująca na popularyzację wśród szerokiego grona odbiorców. 